Agric. Biol. Chem., 42 (3), 529 536, 19/8

\title{
Structure and Synthesis of E-64, a New Thiol Protease Inhibitor ${ }^{\dagger}$
}

\author{
Kazunori Hanada, Masaharu Tamai, Sadafumi Ohmura, \\ Jiro Sawada, Teruya SekI and Ichiro Tanaka \\ Research Laboratories of Taisho Pharmacentical Co., Ltd., \\ 1-403, Yoshinocho, Ohmiya, Saitama, Japan \\ Received July 21, 1977
}

\begin{abstract}
E-64, a new thiol protease inhibitor, was isolated from a mold, as described previously. ${ }^{17}$ This was proved to consist of each one mole of L-leucine, agmatine and L-trans-epoxysuccinic acid by the analysis of the digestion products of E- 64 by pronase. Moreover, the absolute structure of E-64 was assumed to be N-[N-(L-3-trans-carboxyoxiran-2-carbonyl)-L-leucyl]agmatine and the identity was established by the comparison with its optical isomer which was obtained synthetically. The difference of optical activity of trans-epoxysuccinic acid gave no effect on papain inhibitory activity.
\end{abstract}

As described in the preceding paper, ${ }^{1 /}$ E-64, a novel thiol protease inhibitor, was isolated from a culture extract of Asp. japonicus TPR-64 and its physicochemical and biochemical properties were clarified. This paper is concerned with the estimation of the structure of E-64 and with the establishment thereof by chemical synthesis of the related compounds including its optical isomer. The structureactivity relationship of E-64 will be described in the subsequent paper

As mentioned previously, ${ }^{1)}$ E-64 can be obtained as white needles of whose molecular formula was established as $\mathrm{C}_{15} \mathrm{H}_{27} \mathrm{O}_{5} \mathrm{~N}_{5}$ (M.W. 357). This is almost neutral electrophoretically showing approximately similar behavior to that of L-leucine. Positive color reactions of E-64 indicated the presence of guanidyl, epoxide, 1,2-dicarboxyl groups and a peptide bond with a good correspondence with its IR spectrum.

E-64 was cleaved almost completely into three constituents with pronase $E$, all of which were isolated as crysta!s, as mentioned below, whereas hydrolysis with $\mathrm{HCl}$ resulted in the disappearance of epoxide. Table I shows the analytical data of these three constituents.

Component $\mathrm{A}$ has a molecular formula of

$\uparrow$ Studies on Thiol Protease Inhibitors. Part II. See reference 1) for Part I. A part of this paper was presented at the Annual Meeting of the Agricultural and Chemical Society of Japan, Apr. 2, 1977.
$\mathrm{C}_{6} \mathrm{H}_{13} \mathrm{O}_{2} \mathrm{~N}$ and gives a positive ninhydrin test. This is active optically, $[\alpha]_{\mathrm{D}}^{20}-8.5\left(c=2, \mathrm{H}_{2} \mathrm{O}\right)$. In addition, from both the elution pattern on an amino acid autoanalizer and PMR analysis, this was suggested to be L-leucine and the identity was confirmed by direct comparison with an authentic sample.

Component $\mathrm{B}$, strongly basic and positive with ninhydrin and Sakaguchi reactions, was identified as agmatine by spectral comparison in PMR with an authentic sample. In addition, the result of elemental analysis was identical with the calculated value of agmatine $\cdot 2 \mathrm{HCl}$.

Component $\mathrm{C}$, strongly acidic, white prisms, mp $173 \sim 175^{\circ} \mathrm{C},[\alpha]_{\mathrm{D}}^{20}+78\left(c=1, \mathrm{H}_{2} \mathrm{O}\right)$, was clarified to possess epoxide and 1,2-dicarboxyl groups from the positive color reactions and suggested to be trans-epoxysuccinic acid judging from its molecular formula. The identity was confirmed by the comparison with DLtrans-epoxysuccinic acid synthesized by the method of K. Sakaguchi et al. ${ }^{2)}$ on elemental analysis, TLC and spectral analyses (IR, PMR, MS). R. Kuhn et al. ${ }^{3)}$ reported that $(+)$ malic acid was prepared from (-)trans-epoxysuccinic acid, an optical isomer of component $\mathrm{C}$. Another report ${ }^{4}$ also pointed out that the oxiran ring of (-)trans-epoxysuccinic acid was rapidly opened by a simple $\mathrm{S}_{\mathrm{N}} 2$ mechanism with inversion of configuration to give erythro$\beta$-hydroxy-L-aspartic acid when it was warmed 
Table I. Properties of Component A, B, C

\begin{tabular}{|c|c|c|c|c|c|c|}
\hline & \multicolumn{2}{|c|}{ A } & \multicolumn{2}{|c|}{ B } & \multicolumn{2}{|c|}{$\mathrm{C}$} \\
\hline $\mathrm{mp}$ & \multirow{2}{*}{\multicolumn{2}{|c|}{$\begin{array}{l}300^{\circ} \mathrm{C} \\
\text { eutral, plate }\end{array}$}} & \multirow{2}{*}{\multicolumn{2}{|c|}{$\begin{array}{c}178 \sim 178.5^{\circ} \mathrm{C} \\
\text { basic, plate }\end{array}$}} & \multirow{2}{*}{\multicolumn{2}{|c|}{$\begin{array}{l}173 \sim 175^{\circ} \mathrm{C} \\
\text { acidic, prism }\end{array}$}} \\
\hline Nature & & & & & & \\
\hline Elemental analysis & Found & Calcd. & Found & Calcd. & Found & Calcd. \\
\hline $\mathrm{N}$ & 10.68 & 10.67 & 27.43 & 27.58 & - & - \\
\hline C & 54.92 & 54.94 & 29.78 & 29.56 & 36.52 & 36.37 \\
\hline $\mathrm{H}$ & 9.71 & 9.99 & 7.68 & 7.94 & 3.27 & 3.06 \\
\hline $\mathrm{Cl}$ & - & - & 34.40 & 34.91 & - & - \\
\hline $\begin{array}{l}\text { Molecular formula } \\
\text { Positive color reaction }\end{array}$ & \multicolumn{2}{|c|}{$\begin{array}{c}\mathrm{C}_{\beta} \mathrm{H}_{13} \mathrm{O}_{2} \mathrm{~N} \\
\text { ninhydrin }\end{array}$} & \multicolumn{2}{|c|}{$\begin{array}{c}\mathrm{C}_{5} \mathrm{H}_{14} \mathrm{~N}_{4} \cdot 2 \mathrm{HCl} \\
\text { ninhydrin } \\
\text { Sakaguchi }\end{array}$} & \multicolumn{2}{|c|}{$\begin{array}{l}\qquad \mathrm{C}_{4} \mathrm{H}_{4} \mathrm{O}_{5} \\
\text { thiosulfate (epoxide) } \\
\text { Feigle (dicarboxylic acid) }\end{array}$} \\
\hline$[\alpha]_{D}^{20}$ & \multicolumn{2}{|c|}{$-8.5\left(c=2, \mathrm{H}_{2} \mathrm{O}\right)$} & \multicolumn{2}{|l|}{ - } & \multicolumn{2}{|c|}{$+78\left(c=1, \mathrm{H}_{2} \mathrm{O}\right)$} \\
\hline Contents in E-64 & \multicolumn{2}{|l|}{$32.8 \%$} & \multicolumn{2}{|l|}{$35.8 \%$} & \multicolumn{2}{|l|}{-} \\
\hline
\end{tabular}

Table II. Proton Magnetic Resonance Absorptions Assigned to E-64

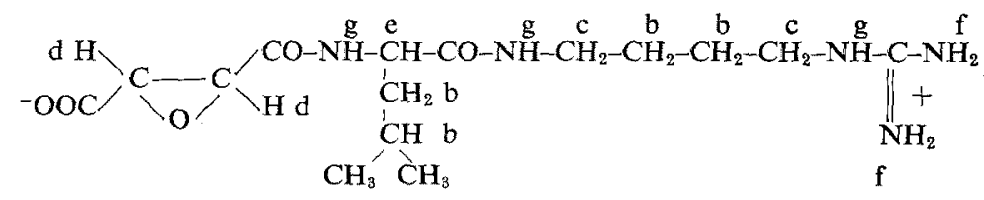

a a

\begin{tabular}{ccccc}
\hline Solvent & $\begin{array}{c}\text { Chemical } \\
\text { shift, ppm }\end{array}$ & Area & Multiplicity & Assignment \\
\hline $\mathrm{D}_{2} \mathrm{O}+\mathrm{DCl}$ & 0.95 & 6 & $\mathrm{br} . \mathrm{s}$ & $\mathrm{a}$ \\
& 1.55 & 7 & $\mathrm{br.s}$ & $\mathrm{b}$ \\
& 3.20 & 4 & $\mathrm{br.s}$ & $\mathrm{c}$ \\
& 3.66 & 1 & $\mathrm{~d}$ & $\mathrm{~d}$ \\
& 3.78 & 1 & $\mathrm{~d}$ & $\mathrm{~d}$ \\
\hline DMSO-d6 & 4.30 & 1 & $\mathrm{t}$ & $\mathrm{e}$ \\
\hline & 0.85 & 6 & $\mathrm{br.s}$ & $\mathrm{a}$ \\
& 1.42 & 7 & $\mathrm{br} . \mathrm{s}$ & $\mathrm{c}$ \\
& 3.05 & 4 & $\mathrm{br.s}$ & $\mathrm{e}$ \\
& 4.25 & 1 & $\mathrm{t}$ & $\mathrm{f}$ \\
\hline
\end{tabular}

with aqueous ammonia. Component $\mathrm{C}$ was, therefore, inferred to be L-trans-epoxysuccinic acid with the absolute configuration of $(2 S, 3 S)$.

Moreover, it was suggested from the molecular weight that E-64 consisted of each one mole of these three components. This was also supported by the analysis of the signals on PMR which were reasonably assigned, as depicted in Table II. In this, the two protons on the oxiran ring of component $\mathrm{C}$, afforded singlet signal, whereas the same protons on E-64 gave double doubllet. This seems to indicate that the circumstances around these two protons on E-64 are different each other, that is, one of carboxyl groups may exist in a combined state, but another one in a free.

In addition, E-64 was negative for ninhydrin test and approximately neutral electrophoretically, as mentioned above.

On the basis of these results, the structure of E-64 can be assumed most reasonably to be $\mathrm{N}$-[N-(L-3-trans-carboxyoxiran-2-carbonyl)-Lleucyl]-agmatine(compound $\mathrm{I}$ ). The synthesis of compound I was carried out independently through two synthetic schemes (Figs. 1 and 2). Herein, L-leucine and DL-trans-epoxysuccinic acid were employed for convenience as starting materials with an expectation that coexisting 

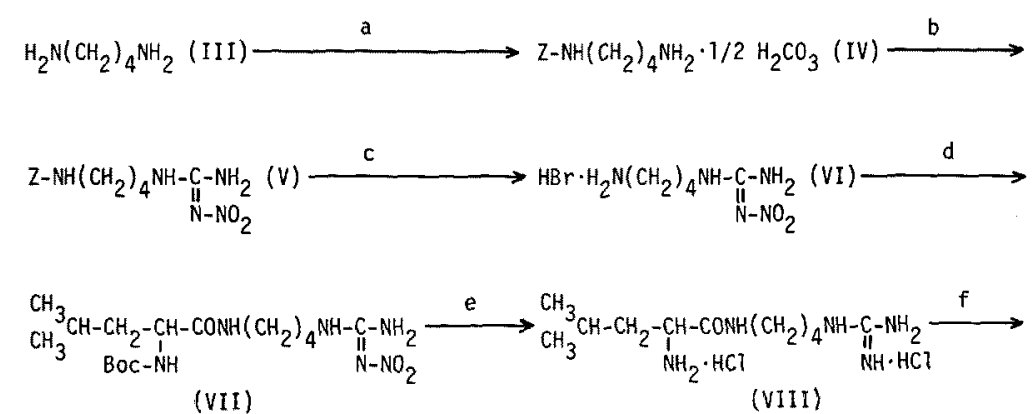

(VII)

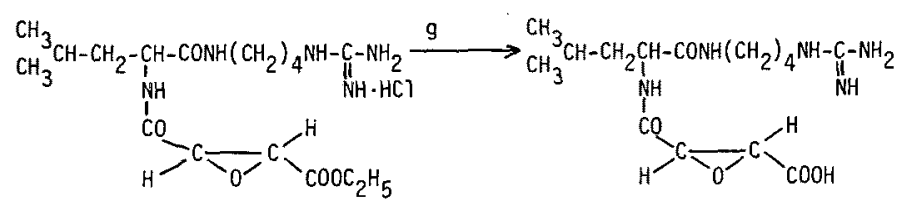

(IX)

(I)

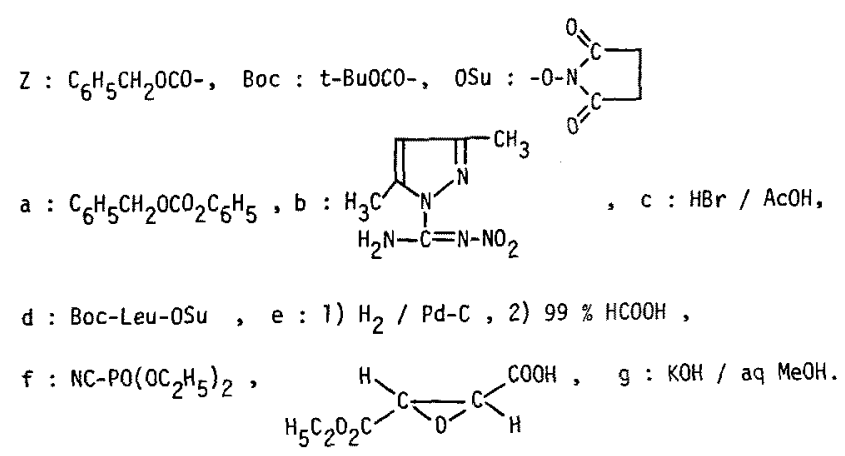

FIG. 1. Synthetic Scheme of E-64 (Scheme 1).

diastereoisomer will be separated favorably in the course of the procedure.

Table III shows the properties of two products synthesized independently via the above two routes, Schemes 1 and 2, and the products were named Synthetic 1 and 2, respectively. These two compounds agreed with natural E-64 on TLC and elemental analyses, and PMR and IR spectra coincided completely except delicate differences illustrated in Fig. 3. Furthermore, both compounds gave an excellent agreement with $\mathrm{E}-64$ on $\mathrm{ID}_{50}$ for papain for $0.3 \times 10^{-9}$ mole.

On the basis of these results, it seems likely that the two synthetic compounds obtained here are identical with natural E-64 in their structural formulae, but not in the absolute configuration of trans-epoxysuccinic acid moiety. This seems to contribute to minute differences in IR and PMR spectra. Comparison of PMR spectra between natural E-64 and synthetic 2 afforded the difference in the chemical shift of the signals due to the two protons on the oxiran ring, which were at $3.66,3.78$ and $3.71,3.78 \mathrm{ppm}$, respectively, as illustrated in Fig. 3. Upon this, it seems likely that transepoxysuccinic acid of synthetic 2 is mostly in D-form in contrast to that of natural E-64. Moreover, synthetic 1 appears to be a mixture of $\mathrm{D}$ and $\mathrm{L}$. The same speculation can also apply to the interpretation of slight differences on the IR spectra indicated by the arrows in Fig. 3.

As mentioned above, the synthesis of the intended compound (compound I) could not be attained, but its optical isomer was obtained as a result. The primary purpose, the elucidation of the structure of E-64, which was de- 


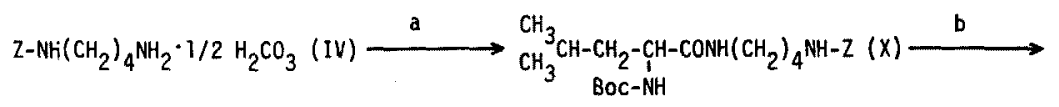

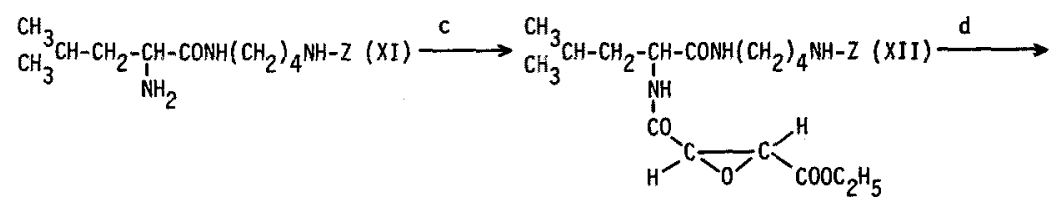

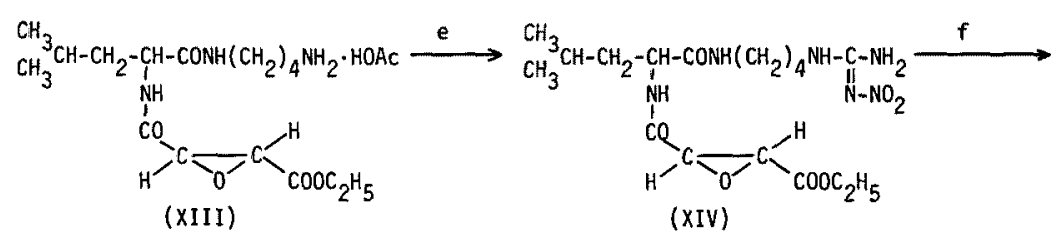

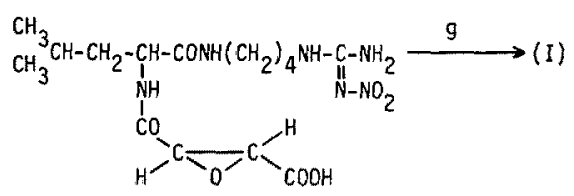

(xv)

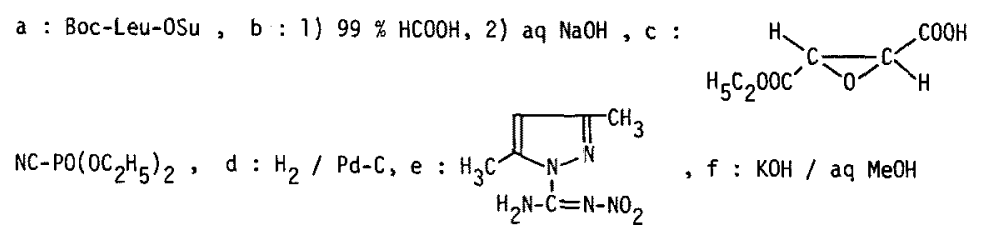

$g: H_{2} / P d-C$

Fro. 2. Synthetic Scheme of E-64 (Scheme 2).

Table III. Physicochemical Properties of Synthetic E-64

\begin{tabular}{|c|c|c|c|c|}
\hline & \multicolumn{2}{|c|}{ Synthetic 1} & \multicolumn{2}{|c|}{ Synthetic 2} \\
\hline Synthetic scheme & \multicolumn{2}{|l|}{ (1) } & \multicolumn{2}{|l|}{ (2) } \\
\hline$m p^{a\rangle}$ & \multicolumn{2}{|c|}{$166 \sim 170^{\circ} \mathrm{C}$ (decomp.) } & \multicolumn{2}{|c|}{$173 \sim 175^{\circ} \mathrm{C}$ (decomp.) } \\
\hline$[\alpha]_{D}^{b\rangle}$ & \multicolumn{2}{|c|}{$-69.5^{\circ}(c=0.4560 .1 \mathrm{~N} \mathrm{HCl})$} & \multicolumn{2}{|c|}{$-80.6^{\circ}(c=0.4560 .1 \mathrm{~N} \mathrm{HCl})$} \\
\hline Elemental analysis & Found & Caled. & Found & Calcd. \\
\hline$N$ & 17.95 & 17.80 & 17.82 & 17.80 \\
\hline $\mathrm{C}$ & 45.75 & 45.79 & 45.73 & 45.79 \\
\hline $\mathrm{H}$ & 7.91 & 7.94 & 7.90 & 7.94 \\
\hline $\begin{array}{l}\text { Molecular formula } \\
\text { TLC (cellulose) }\end{array}$ & \multicolumn{2}{|c|}{$\mathrm{C}_{15} \mathrm{H}_{27} \mathrm{~N}_{5} \mathrm{O}_{5} \cdot 2 \mathrm{H}_{2} \mathrm{O}$} & \multicolumn{2}{|c|}{$\mathrm{C}_{15} \mathrm{H}_{2 \tau} \mathrm{N}_{5} \mathrm{O}_{5} \cdot 2 \mathrm{H}_{2} \mathrm{O}$} \\
\hline $\mathrm{BuOH}: \mathrm{AcOH}: \mathrm{H}_{2} \mathrm{O}=4: 1: 2$ & \multicolumn{2}{|c|}{ agreement with $E-64$} & \multicolumn{2}{|c|}{ agreement with E-64 } \\
\hline$n$-ProOH: $\mathrm{H}_{2} \mathrm{O}=7: 3$ & \multicolumn{2}{|c|}{$\Rightarrow$} & \multicolumn{2}{|c|}{ " } \\
\hline Positive color reaction & \multicolumn{2}{|c|}{ Sakaguchi, thiosulfate } & \multicolumn{2}{|c|}{ Sakaguchi, thiosulfate } \\
\hline
\end{tabular}

a) Natural E-64 $=180 \sim 182^{\circ} \mathrm{C}$ b) Natural E-64 $=+24.4$ 


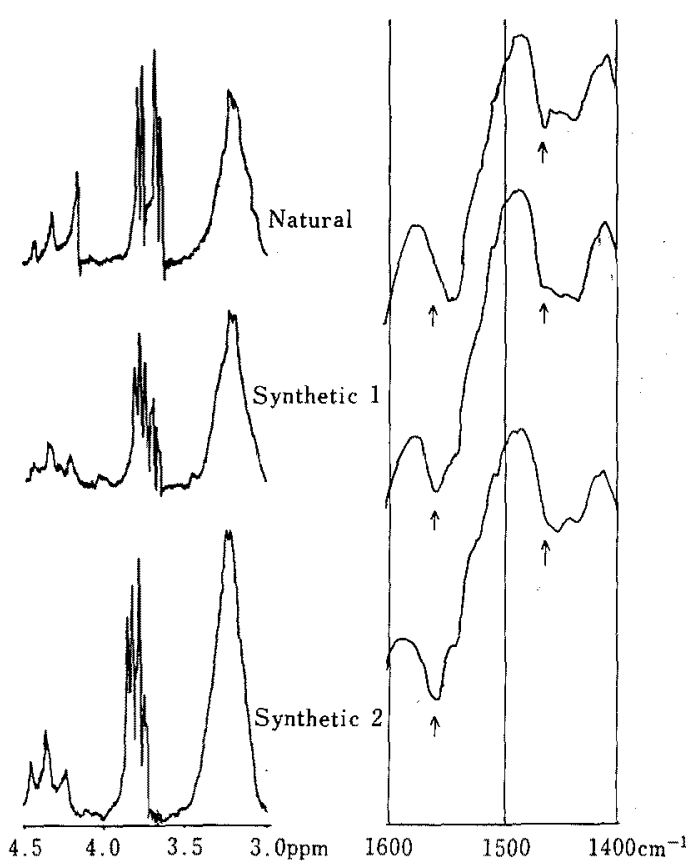

Fig. 3. Comparisons among Natural E-64, Synthetic 1 and 2 on PMR and IR Spectra.

termined to be $\mathrm{N}-[\mathrm{N}$-(L-trans-carboxyoxiran-2carbonyl)-L-leucyl]-agmatine, has, however, been achieved through the information on the related compound obtained synthetically.

\section{EXPERIMENTAL}

General methods. IR spectra were recorded on a Model DS $70 G$ spectrometer, Japan Spectroscopic Co., Japan and PMR spectra were measured at $60 \mathrm{MHz}$ with a Model R-20 spectrometer, Hitachi-Perkin-Elmer Co. Optical rotations were determined on a Model DIP-4 polarimeter, Japan Spectroscopic Co. Aminoacid analysis was carried out by use of a Hitachi KLA5 amino acid autoanalyzer.

Assay of inhibitory activity for papain. Inhibitory activity for papain was determined by the method described previously. ${ }^{11}$

Hydrolysis of E-64 by pronase $E$ and isolation of the products. A water solution $(35 \mathrm{ml})$ containing both E-64 (300 mg) and pronase E (40 mg) which was purchased from Junsei Pure Chem. Co. and further purified through a Sephadex G-25 column was incubated at $30^{\circ} \mathrm{C}$ for two days and followed by the gelfiltration on a Sephadex G-25 column in order to eliminate the used enzyme. The low molecular fractions were combined and concentrated to $10 \mathrm{ml}$. This was submitted to a column of phosphocellulose $\left(\mathrm{H}^{+}\right.$ type, $100 \mathrm{ml}$ ) and eluted into three fractions, that is the acidic fraction (non-adsorbed), the neutral (eluted with water) and the basic (eluted with $0.1 \times \mathrm{HCl}$ ). Evaporation of the neutral fraction gave white powder, which on crystallization from aqueous ethanol was obtained as white plates and designated as Component A $(65.5 \mathrm{mg}$, $68 \%$ ). From the basic fraction, white plates were obtained in the same manner and named Component B $(100 \mathrm{mg}, 60 \%)$. The acidic fraction was acidified with $\mathrm{H}_{2} \mathrm{SO}_{4}$ and extracted with ethylether $(20 \mathrm{ml} \times 2)$. The ethylether layer was concentrated and followed by addition of petroleum ether to give white prisms designated as Component $\mathrm{C}(62 \mathrm{mg}, 56 \%)$.

Benzyl phenyl carbonate. Benzyl phenyl carbonate was prepared according to the method of $\mathrm{H}$. Zahn et $a$ bi $^{\text {s }}$

1-Nitroguanyl-3, 5-dimethyl-pyrazole. 1-Nitroguanyl-3, 5-dimethyl-pyrazole was synthesized from guanidine nitrate via nitroguanidine and nitroaminoguanidine. ( $^{\theta-8)}$

DL-Ethyl hydrogen trans-epoxysuccinate (II). DLtrans-Epoxysuccinic acid was prepared from fumaric acid by the method of Payne et al. ${ }^{\text {p) }}$ A solution of DL-trans-epoxysuccinic acid $(19.7 \mathrm{~g})$ and conc. sulfuric acid $(6 \mathrm{~g})$ in abs. EtOH $(200 \mathrm{ml})$ was refluxed for $6 \mathrm{hr}$ and then was brought to $\mathrm{pH} 7$ with $10 \% \mathrm{Na}_{2} \mathrm{CO}_{3}$ solution. After removal of ethanol by evaporation, the residue was suspended into $2 \% \mathrm{Na}_{2} \mathrm{CO}_{3}$ solution and extracted with AcOEt $(100 \mathrm{ml} \times 2)$. The organic layer was washed with $2 \% \mathrm{HCl}$ and sat. $\mathrm{NaCl}$ in turn, dried over $\mathrm{MgSO}_{4}$ and evaporated to an oil. The fractional distillation of the resulting oil gave $16.7 \mathrm{~g}$ of diethyl epoxysuccinate as a colorless oil (bp $84 \sim 91^{\circ} \mathrm{C}, 3$ $\mathrm{mmHg}$ ). To an ethanolic solution $(50 \mathrm{ml})$ of diethyl epoxysuccinate $(13.1 \mathrm{~g})$, was added an ethanolic solution $(120 \mathrm{ml})$ of $\mathrm{KOH}(3.94 \mathrm{~g})$ under ice cooling and stirred for $2 \mathrm{hr}$ at the same temperature. The deposited solid was filtered off and crystallized from aqueous EtOH to give white prisms of DL-ethyl potassium transepoxysuccinate $\left(11.75 \mathrm{~g}\right.$ ), mp $283^{\circ} \mathrm{C}$ (decomp.). Anal. Calcd. for $\mathrm{C}_{6} \mathrm{H}_{7} \mathrm{O}_{5} \mathrm{~K}: \mathrm{C}, 36.36 ; \mathrm{H}, 3.56$. Found: $\mathrm{C}, 36.13 ; \mathrm{H}, 3.75$. PMR $\left(\mathrm{D}_{2} \mathrm{O}\right) \delta: 1.29(3 \mathrm{H}, \mathrm{t}, J=$ $6.6 \mathrm{~Hz}), 3.55(2 \mathrm{H}, \mathrm{d} . \mathrm{d}, J=2.0 \mathrm{~Hz}), 4.25(2 \mathrm{H}, \mathrm{q}, J=$ $6.6 \mathrm{~Hz})$. The aqueous solution $(50 \mathrm{ml})$ of DL-ethyl potassium trans-epoxysuccinate $(10.46 \mathrm{~g})$ was saturated with $\mathrm{NaCl}$, acidified with conc. $\mathrm{HCl}$ and extracted with AcOEt $(30 \mathrm{ml} \times 3)$. The combined organic layer was washed with sat. $\mathrm{NaCl}$ and evaporated to a colorless oil of (II) $(6.95 \mathrm{~g})$. bp $116 \sim 119^{\circ} \mathrm{C}(0.3 \mathrm{mmHg})$.

N-Carbobenzoxy-1, 4-diaminobutane carbonate (IV). $\mathrm{HCl}$ salt of IV was prepared from III (22.3 g) and benzyl phenyl carbonate $(57.1 \mathrm{~g})$ by the method similar to that described by J. S. Rao. ${ }^{10)}$ A suspension of $\mathrm{HCl}$ salt of IV in water $(200 \mathrm{ml})$ was made alkali with $\mathrm{NaOH}(10 \mathrm{~g})$ and extracted with AcOEt $(100 \mathrm{ml} 3)$. 
The organic layer was washed with sat. $\mathrm{NaCl}$, concentrated to about $150 \mathrm{ml}$ and treated with dry ice to deposit a solid. The solid was filtered off after chilling for a few hours and washed with AcOEt and water in turn. Recrystallization from EtOH gave colorless solid of IV $(36.76 \mathrm{~g}), \mathrm{mp} 127 \sim 133^{\circ} \mathrm{C}$.

$N$-Carbobenzoxy- $N^{G}$-nitroagmatine $(V)$. A solution of IV $(8.0 \mathrm{~g})$, 1-nitroguanyl-3, 5-dimethylpyrazole ${ }^{\mathrm{B})}$ $(6.2 \mathrm{~g})$ and triethylamine $(2.84 \mathrm{~g})$ in EtOH $(80 \mathrm{ml})$ was heated under reflux for $2 \mathrm{hr}$ and then chilled overnight. The deposited solid was filtered off and washed with a small amount of EtOH. Recrystallization from EtOH gave $7.55 \mathrm{~g}$ of a colorless solid of $\mathrm{V}, \mathrm{mp} 122 \sim$ $124^{\circ} \mathrm{C}$.

$N^{G}$-Nitroagmatine hydrobromide (VI). VI was synthesized from $\mathrm{V}$ by the method similar to that described by W. D. J. Johnson et al. ${ }^{11)}$ and obtained as colorless solid, mp $174 \sim 176^{\circ} \mathrm{C}$ (decomp.).

$N-(B o c-\mathrm{L}-l e u c y l)-N^{G}-$ nitroagmatine (VII). A solution of VI $(3.9 \mathrm{~g})$ and triethylamine $(1.69 \mathrm{~g})$ in water $(9 \mathrm{ml})$ was added to a cooled solution of Boc-L-Leu$\mathrm{OSu}^{12)}(4.99 \mathrm{~g})$ in DME (dimethoxyethane) $(50 \mathrm{ml})$ to give a suspension which become clear on $5.5 \mathrm{hr}$ stirring. The solution was concentrated to about $15 \mathrm{ml}$, diluted with $2.5 \% \mathrm{Na}_{2} \mathrm{CO}_{3}$ solution $(40 \mathrm{ml})$ and then the whole was extracted with AcOEt $(40 \mathrm{ml} \times 2)$. The AcOEt layer was washed with $1 \mathrm{M}$ citric acid and sat. $\mathrm{NaCl}$ and evaporated to dryness, followed by chromatography on a silicagel column $(200 \mathrm{~g})$. Elution with AcOEt in acetone (2:1) subsequent to AcOEt in isopropylether $(2: 1)$ affored $5.7 \mathrm{~g}$ of glass of VII which was determined by IR and PMR analyses.

$\mathrm{N}$-L-Leucyl agmatine.2HCl (VIII). A solution VII $(3.15 \mathrm{~g})$ in $\mathrm{MeOH}(40 \mathrm{ml})$, acetic acid $(8 \mathrm{ml})$ and water $(4 \mathrm{ml})$ was stirred under $\mathrm{H}_{2}$ stream in the presence of $10 \% \mathrm{Pd}-\mathrm{C}(0.4 \mathrm{~g})$ at room temperature for $4 \mathrm{hr}$. After removal of the catalyst by filtration, the filtrate was evaporated to an oil. An aqueous solution of water layer gave $2.99 \mathrm{~g}$ of a caramel of an acetic acid salt of N-Boc-L-leucyl agmatine. The salt was dissolved in $99 \%$ formic acid $(120 \mathrm{ml})$ and then the solution was evaporated keeping the temperature below $30^{\circ} \mathrm{C}$ after stirring at room temperature for $3 \mathrm{hr}$. An aqueous solution $(40 \mathrm{ml})$ of the residue was washed with AcOEt and applied to a column of Amberlite IRC$50\left(\mathrm{H}^{+}, 48 \mathrm{ml}\right)$. After washing with water, the column was eluted with $2 \mathrm{~N} \mathrm{HCl}$ and the eluate was evaporated to give $1.8 \mathrm{~g}$ of glass of VIII, which was identified by IR and PMR analyses.

$N-[N-(\mathrm{D}-$ and L-3-trans - Ethoxycarbonyloxiran-2carbonyl)-L-leucyl] agmatine $\mathrm{HCl}(I X)$. To a solution of II $(1.0 \mathrm{~g})$ and VIII $(1.7 \mathrm{~g})$ in DMF (Dimethyl formamide) $(11 \mathrm{ml})$ were added a solution of diethylphosphorylcyanide ${ }^{13)}(1.05 \mathrm{~g})$ in DMF $(11 \mathrm{ml})$ and that of triethylamine $(1.38 \mathrm{~g})$ in DMF $(2 \mathrm{ml})$ in turn under cooling. The suspension was stirred under ice cooling for an hour and at room temperature for further $4 \mathrm{hr}$. After removal of the deposited solid by filtration, ethylether $(200 \mathrm{ml})$ was added to the filtrate and the whole was left overnight in a refrigerator. The resulting oil was separated by decantation and subjected to a silicagel column (70 g) followed by the development with $33 \%$ EtOH in $\mathrm{CHCl}_{3}$, The fractions positive with Sakaguchi reaction were combined and evaporated to give $0.75 \mathrm{~g}$ of a colorless solid of IX which was identified by IR and PMR analyses.

$N$-[N-(D- and L-3-trans-Carboxyoxiran-2-carbonyl)L-leucyl] agmatine $\left(I+I^{\prime}\right)$. To a methanolic solution $(5 \mathrm{ml})$ of IX $(0.64 \mathrm{~g})$, was added $2 \mathrm{~N} \mathrm{KOH}$ solution $(1.5 \mathrm{ml})$ under ice cooling and left at room temperature for $3 \mathrm{hr}$. After neutralization with $10 \% \mathrm{HCl}$, the solution was evaporated to dryness. An aqueous solution of the residue was applied to an active charcoal column. After washing with water, the elution was carried out with aqueous acetone $(1: 1)$. The eluate was evaporated to give a solid. Recrystallization from hot waterEtOH afforded $0.15 \mathrm{~g}$ of colorless solid, which was found to be a mixture of $\mathrm{I}$ and $\mathrm{I}^{\prime}, \operatorname{mp} 185 \sim 190^{\circ} \mathrm{C}$ (decomp.), Anal. Calcd. for $\mathrm{C}_{15} \mathrm{H}_{27} \mathrm{~N}_{5} \mathrm{O}_{5} \cdot 2 \mathrm{H}_{2} \mathrm{O}: \mathrm{C}, 45.79 ; \mathrm{H}$, 7.94; N, 17.80. Found: C, 45.75, H, 7.91; N, 17.95. PMR $\delta: 0.8 \sim 1.0(6 \mathrm{H}$, br. s), $1.4 \sim 1.8$ (7H, br. s), $3.0 \sim$ $3.4(4 \mathrm{H}$, br. s), 3.66, 3.78, and $3.71,3.78(2 \mathrm{H}$, two pair of d. d, $J=1.8 \mathrm{~Hz}), 4.32(1 \mathrm{H}, t, J=7.2 \mathrm{~Hz}) . \quad \operatorname{IR} \nu_{\mathrm{max}}^{\mathrm{KBr}}$ $\mathrm{cm}^{-1}: 3285(\mathrm{NH}), 1642(\mathrm{C}=\mathrm{O}), 1560,1545,1465$, $1388,895 .[\alpha]_{\mathrm{D}}^{16}-69.5(c=0.463,0.1 \mathrm{~N} \mathrm{HCl})$.

N-(Boc-L-leucyl) N'-carbobenzoxy-1, 4-diaminobutane $(X)$. To a suspension of IV $(8.53 \mathrm{~g})$ and triethylamine $(3.04 \mathrm{~g})$ in water $(12 \mathrm{ml})$ and DMF $(80 \mathrm{ml})$, a solution of Boc-L-Leu-O-Su $(9.86 \mathrm{~g})$ in DMF $(70 \mathrm{ml})$ was added and stirred at room temperature for $1.5 \mathrm{hr}$. After concentration to $30 \mathrm{ml}$, the residue was shaken with $2 \% \mathrm{Na}_{2} \mathrm{CO}_{3}$ solution $(100 \mathrm{ml})$ and then with AcOEt $(150 \mathrm{ml} \times 2)$. The organic layer was washed with $1 \mathrm{M}$ citric acid and sat. $\mathrm{NaCl}$ in turn and evaporated to an oil which solidified later. The solid was submitted to a silicagel column $(500 \mathrm{~g})$ and eluted with AcOEt: $\mathrm{CHCl}_{3}$ : isopropylether $=20 / 10 / 3$. The purified fractions were combined and evaporated to a solid, from which on recrystallization from isopropyletherAcOEt was obtained $12.03 \mathrm{~g}$ of $\mathrm{X}$ as colorless crystals, mp $88 \sim 89.5^{\circ} \mathrm{C}$. Anal. Calcd. for $\mathrm{C}_{22} \mathrm{H}_{37} \mathrm{~N}_{3} \mathrm{O}_{5}: \mathrm{C}$, $63.42 ; \mathrm{H}, 8.56 ; \mathrm{N}, 9.65$. Found: C, 63.72; H, 8.80; $\mathrm{N}, 9.45 .[\alpha]_{\mathrm{D}}^{12}-24.3(c=0.503$, dioxane $)$,

$N$-Carbobenzoxy-N'-L-leucyl-1, 4-diaminobutane $(X I)$. A solution of $X(7.0 \mathrm{~g})$ in $99 \%$ formic acid $(183 \mathrm{ml})$ was left at room temperature for $3 \mathrm{hr}$. After removal of formic acid by evaporation in vacuo keeping the temperature below $30^{\circ} \mathrm{C}$, the resulting oil was taken in ethylether $(100 \mathrm{ml})$ and allowed to stand overnight in a 
refrigerator to give colorless solid which on recrystallization from AcOEt was obtained as colorless needles of the formic acid salt of XI $(5.5 \mathrm{~g}), \mathrm{mp} 101 \sim 102^{\circ} \mathrm{C}$, $[\alpha]_{\mathrm{D}}^{13}+9.1 \quad(c=0.506, \mathrm{MeOH})$. Anal. Calcd. for $\mathrm{C}_{19} \mathrm{H}_{29} \mathrm{~N}_{3} \mathrm{O}_{3} \cdot \mathrm{HCOOH}: \mathrm{C}, 59.82 ; \mathrm{H}, 8.19 ; \mathrm{N}, 11.02$. Found: $\mathrm{C}, 60.04 ; \mathrm{H}, 8.30 ; \mathrm{N}, 11.09$. An aqueous solution of the salt was treated with $\mathrm{NaOH}$ and then extracted with $\mathrm{CHCl}_{3}(50 \mathrm{ml} \times 3)$. After washing with water, the organic layer was evaporated to give a colorless solid of XI $(4.8 \mathrm{~g})$.

$N$-Carbobenzoxy- $N^{\prime}-[N-(\mathrm{D}-$ and L-3-trans-ethoxycarbonyloxiran-2-carbonyl)-L- leucyl]-1, 4-diaminobutane (XII). To a solution of XI (2.835 g) and II (1.36 g) in DMF $(40 \mathrm{ml})$, were added a solution of diethylphosphorylcyanide $(1.52 \mathrm{~g})$ in DMF $(10 \mathrm{ml})$ and triethylamine $(1.1 \mathrm{~g})$ at $0^{\circ} \mathrm{C}$ in turn. After stirring at room temperature for $4 \mathrm{hr}$, the solution was diluted with AcOEt $(150 \mathrm{ml})$ and benzene $(100 \mathrm{ml})$. The organic

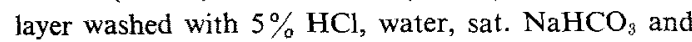
sat. $\mathrm{NaCl}$ in turn was evaporated to dryness. The resulting solid was reprecipitated from AcOEt-isopropylether to give a colorless powder of XII $(3.11 \mathrm{~g})$, $\operatorname{mp} 104 \sim 107^{\circ} \mathrm{C}, \quad[\alpha]_{\mathrm{D}}^{14}-23.1^{\circ} \quad(c=0.506$, dioxane $)$, Anal. Calcd. for $\mathrm{C}_{24} \mathrm{H}_{35} \mathrm{~N}_{3} \mathrm{O}_{7}: \mathrm{C}, 60.36 ; \mathrm{H}, 7.39 ; \mathrm{N}$, 8.80. Found: $\mathrm{C}, 60.07 ; \mathrm{H}, 7.54 ; \mathrm{N}, 8.75$.

$N-[N-$ (D- and L-3-trans-Ethoxycarbonyloxiran-2 carbonyl)-L-leucyll-1, 4-diaminobutane acetate (XIII). A solution of XII $(1.54 \mathrm{~g})$ in EtOH $(24 \mathrm{ml})$, acetic acid $(6 \mathrm{ml})$ and water $(3 \mathrm{ml})$ was stirred at room temperature under hydrogen atmosphere in the presence of $10 \%$ Pd-C $(0.15 \mathrm{~g})$ for $3 \mathrm{hr}$. After removal of catalyst by filtration, the filtrate was evaporated. The aqueous solution of the residue was washed with AcOEt and then evaporated to give a colorless glass of XIII $(1.3 \mathrm{~g})$ which was identified by PMR analysis.

$N-[N$ - (D-and L-3-trans - Ethoxycarbonyloxiran-2 carbonyl)-L-leucyl]- $N^{a}$-nitroagmatine $(X I V)$. A solution of XIII $(3.2 \mathrm{~g})$, triethylamine $(0.96 \mathrm{~g})$ and $3,5-$ dimethyl-1-nitroguanylpyrazole $(1.74 \mathrm{~g})$ in EtOH (100 $\mathrm{ml}$ ) was heated under reflux for $3 \mathrm{hr}$. After removal of the solvent by distillation, the residue was washed with ethylether and extracted with hot AcOEt. The AcOEt layer was washed with $1 \mathrm{M}$ citric acid and water and then evaporated to give a solid, which was submitted to a silicagel column $(30 \mathrm{~g})$. Elution with AcOEt in acetone $(2: 1)$ subsequent to AcOEt gave $1.21 \mathrm{~g}$ of XIV, which on recrystallization from hot AcOEtisopropylether was obtained as colorless amorphous solid. mp $135 \sim 140^{\circ} \mathrm{C},[\alpha]_{\mathrm{D}}^{14}-21.7(c=0.502$, EtOH), Anal. Calcd. for $\mathrm{C}_{17} \mathrm{H}_{20} \mathrm{~N}_{8} \mathrm{O}_{7}: \mathrm{C}, 47.43 ; \mathrm{H}, 7.03$; $\mathrm{N}, 19.52$. Found: $\mathrm{C}, 47.67 ; \mathrm{H}, 7.15 ; \mathrm{N}, 19.26$.

$N-[N-(\mathrm{D}-$ and L-3-trans-Carboxyoxiran-2-carbonyl)-Lleucyl]-NG-nitroagmatine $(X V)$. To a methanolic solution (4 m1) of XIV $(0.594 \mathrm{~g})$, was added $2 \mathrm{~N} \mathrm{KOH}$ solution $(0.76 \mathrm{ml})$ under ice cooling and left at room temperature for $4 \mathrm{hr}$. The solution was diluted with water $(20 \mathrm{ml})$ and neutalized with Dowex $50 \mathrm{~W}\left(\mathrm{H}^{+}\right.$, $4 \mathrm{ml}$ ). After removal of the resin by filtration, the filtrate was evaporated to dryness. The resulting solid was crystallized from water to give $0.352 \mathrm{~g}$ of colorless powder of $\mathrm{XV}, \mathrm{mp} 170 \sim 173^{\circ} \mathrm{C}$ (decomp.), $[\alpha]_{D}^{12}-22.2^{\circ}$ $(c=0.482, \mathrm{MeOH})$. Anal. Calcd. for $\mathrm{C}_{15} \mathrm{H}_{20} \mathrm{~N}_{8} \mathrm{O}_{7}: \mathrm{C}$, $44.77 ; \mathrm{H}, 6.51 ; \mathrm{N}, 20.89$. Found: C, 44.53; H, 6.50; $\mathrm{N}, 20.59$.

$N-[N$-(D-3-trans-Carboxyoxiran-2-carbonyl)-L-leucyl]agmatine $\left(I^{\prime}\right)$. A solution of XV $(0.453 \mathrm{~g})$ in $\mathrm{MeOH}(20 \mathrm{ml})$, acetic acid $(2 \mathrm{ml})$ and water was treated with $10 \% \mathrm{Pd}-\mathrm{C}(0.07 \mathrm{~g})$ at room temperature under stream of $\mathrm{H}_{2}$ for $5 \mathrm{hr}$. After removal of the catalyst, the solution was evaporated. The aqueous solution of the residue was applied to a column of charcoal $(15 \mathrm{ml})$. Elution with $50 \%$ aqueous acetone subsequent to washing with water gave $0.156 \mathrm{~g}$ of a dihydrate of $\mathrm{I}^{\prime}$, which on crystallization from EtOH-water was obtained as colorless crystals, mp $173 \sim 175^{\circ} \mathrm{C}$ (decomp.). Anal. Calcd. for $\mathrm{C}_{15} \mathrm{H}_{27} \mathrm{~N}_{6} \mathrm{O}_{5} \cdot 2 \mathrm{H}_{2} \mathrm{O}: \mathrm{C}, 45.79 ; \mathrm{H}, 7.94 ; \mathrm{N}$, 17.80. Found: $\mathrm{C}, 45.73 ; \mathrm{H} ; 7.90 ; \mathrm{N}, 17.82$. PMR $\left(\mathrm{D}_{2} \mathrm{O}+\mathrm{DCl}\right) \delta: 0.8 \sim 1.1(6 \mathrm{H}$, br. $\mathrm{s}), 1.4 \sim 1.8(7 \mathrm{H}$, br. s), $3.1 \sim 3.4(4 \mathrm{H}$, br. s), $3.71,3.78(2 \mathrm{H}, \mathrm{d} . \mathrm{d}, J=$ $1.8 \mathrm{~Hz}), 4.33(1 \mathrm{H}, \mathrm{t}, J=6.6 \mathrm{~Hz})$. IR $\nu_{\max }^{\mathrm{KBP}} \mathrm{cm}^{-1}$ : $3236(\mathrm{NH}), 1638(\mathrm{C}=\mathrm{O}), 1560,1454,1390,895 .[a]_{D}^{18}$ $-80.6^{\circ}(c=0.454,0.1 \mathrm{~N} \mathrm{HCl})$, TLC (cellulose): $R f=$ 0.58 (BuOH: $\mathrm{AcOH}:$ water $=4 / 1 / 2), 0.67$ ( $n-\mathrm{ProOH}$ : water $=7 / 3$ ).

Acknowledgements. We thanks Mr. S. Uehara, the president of our company for his permission of the publication of this paper and also Mr. B. Terashima, the executive director, for his encouragement.

\section{REFERENCES}

1) H. Hanada, M. Tamai, M. Yamagishi, S. Ohmura, J. Sawada and I. Tanaka, Agric. Biol. Chem., 42, 523 (1978).

2) K. Sakaguchi, T. Inoue and Y. Tada, Nippon Nôgeikagaku Kaishi, 14, 362 (1938).

3) R. Kuhn und R. Zell, Ber., 59, 2514 (1926).

4) M. W. Miller, J. Med. Chem., 6, 233 (1963).

5) H. Zahn und F. Schmidt, Maklomolekulare Chem, 36, 1 (1960).

6) A.F.S. A. Habeeb, Biochim. Biophys. Acta, 93, 533 (1964).

7) T. L. Davis, A. A. Ashdown and H. R. Couch, J. Am. Chem. Soc., 47, 1063 (1925).

8) R. A. Henry, R. C. Makosky and G. B. L. Smith, ibid., 73, 474 (1951). 
9) G. B. Payne and P. H. Williams, J. Org. Chem., 24, 54 (1959).

10) J. S. Rao, Hoppe-Seylers' Z. Physiol. Chem., 349, 251 (1968).

11) W. D. Johnson, H. D. Law and R. O. Studer,
Experientia, 25, 573 (1969).

12) G. W. Anderson, J. E. Zimmerman and F. M. Callahan, J. Am. Chem. Soc., 86, 1839 (1964).

13) S. Yamada, Y. Kasai and T. Shioiri, Tetrahedron Lett., 1973, 1595. 